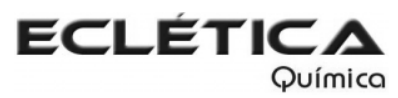

www.scielo.br/eq

www.ecletica.iq.unesp.br

Volume 32, número 4, 2007

\title{
Spectrophotometric determination of mosapride in pure and pharmaceutical preparations
}

\author{
H. D. Revanasiddappa* and M. A. Veena \\ Department of Chemistry, University of Mysore,Manasagangothri, Mysore-570 006, India . \\ *hdrevanasiddappa@yahoo.com
}

\begin{abstract}
Two simple and sensitive spectrophotometric methods $\left(\mathrm{M}_{1}\right.$ and $\left.\mathrm{M}_{2}\right)$ for the determination of mosapride in pure and in pharmaceutical preparations are described. These methods are based on the interaction of diazotized mosapride (MSP) couples with chromotropic acid (CTA) $\left[\mathrm{M}_{1}\right]$ in alkaline medium and diphenylamine (DPA) $\left[\mathrm{M}_{2}\right]$ in acidic medium. The resulting azo-dyes exhibit maximum absorption at $560 \mathrm{~nm}$ and at $540 \mathrm{~nm}$ for methods $\mathrm{M}_{1}$ and $\mathrm{M}_{2}$, respectively. All variables were studied in order to optimize the reaction conditions. No interferences were observed from excipients, and the validity of the each method was tested against reference method.
\end{abstract}

Keywords: mosapride; chromotropic acid; diphenylamine; spectrophotometry; pharmaceutical analysis.

\section{Introduction}

Mosapride citrate, chemically ( \pm )-4amino-5-chloro-2-ethoxy- $N$-(4-( $p$-fluorobenzyl)-2 morpholinyl)methyl)-benzamide, is a potent gastroprokinetic drug and it is used in gastrointestinal symptoms associated with chronic gastritis. It behaves as a selective 5- $\mathrm{HT}_{4}$-receptor agonist and enhances only upper gastroprokinetic motor activity $[1,2]$. The literature survey revealed that only a few methods have been reported for the determination of mosapride (MSP) in pure and in dosage forms and these include HPLC [3-5], spectrofluorometric [6] and spectrophotometric methods [7, 8]. In spectrophotometric methods, Kuchekar et al. [7] have employed $N$-(1-naphthyl)-ethylene diamine dihydrochloride (NEDA) as the coupling reagent for the assay of mosapride, whereas in other method [8], NEDA, $N$-methyl aniline and $N$ phenyl aniline as the coupling agents. These reagents are believed to be carcinogenic and these methods are not too sensitive and obeyed Beer's law in the concentration range of $20-160$ $\mu \mathrm{g} \mathrm{mL}^{-1}$ and 2-10 $\mu \mathrm{g} \mathrm{mL}^{-1}$ in the methods [7] and [8], respectively.

CTA is a well known coupling agent, which has been used for the determination of formaldehyde [9], chloride [10] and dipyridamole and chlorpeniramine maleate [11]. DPA is also used as the coupling agent in the determination of nitrite [12], nitrate13] and guanazole [14]. The present paper describes, facile, sensitive and cost-effective spectrophotometric methods for the assay of mosapride in pure as well as in pharmaceutical samples using cheaper and non-toxic reagents such as chromotropic acid (CTA) and diphenylamine (DPA) as the coupling agents.

\section{Experimental details}

\section{Apparatus}

All absorbance measurements were made 
with ANALYTIC JENA AG model SPECORD50 and SYSTRONICS-166 spectrophotometers with $1 \mathrm{~cm}$ matched cells.

\section{Reagents}

All chemicals used were of analytical reagent grade

Chromotropic acid (CTA) $[0.2 \%(\mathrm{~m} / \mathrm{v})]$ : Prepared by dissolving $0.2 \mathrm{~g}$ of CTA $(\mathrm{BDH})$ in $100 \mathrm{~mL}$ of distilled water.

Diphenylamine (DPA)[0.5 \% $\quad(\mathrm{m} / \mathrm{v})]$ : Prepared by dissolving $0.5 \mathrm{~g}$ DPA (BDH) in 100 $\mathrm{mL}$ of methanol.

Others: Aqueous solutions of sodium nitrite (Merck) $[0.1 \% \quad(\mathrm{~m} / \mathrm{v})]$, sulphamic acid (BDH) $[2.0 \%(\mathrm{~m} / \mathrm{v})]$, sodium hydroxide (Merck) ( $4 \mathrm{~mol} \mathrm{~L}^{-1}$ ) and hydrochloric acid ( $1 \mathrm{~mol} \mathrm{~L}^{-1}$ and $\left.6 \mathrm{~mol} \mathrm{~L}^{-1}\right)$ were used.

\section{Standard solution}

Aqueous solution of mosapride (received as gift sample from Cipla Ltd, Mumbai, India. and used as such) was prepared by dissolving the required amount of the sample in doubly distilled water. Working solution was prepared as required by dilution.

\section{Standard Procedure}

Method $M_{1}$

Aliquots of the standard solution containing $2.0-16.0 \mu \mathrm{g} \mathrm{mL}^{-1}$ of MSP were transferred into a series of $10 \mathrm{~mL}$ standard flasks. A volume of $1.0 \mathrm{~mL}$ of $0.2 \%(\mathrm{~m} / \mathrm{v})$ sodium nitrite was added to each flask followed by $1.0 \mathrm{~mL}$ of 1.0 $\mathrm{mol} \mathrm{L}-1 \mathrm{HCl}$. After $10 \mathrm{~min}, 1.0 \mathrm{~mL}$ of $2.0 \%(\mathrm{~m} / \mathrm{v})$ sulphamic acid was added to each flask. Then volumes of $1.0 \mathrm{~mL}$ of $0.2 \%(\mathrm{~m} / \mathrm{v})$ CTA and 2.0 $\mathrm{mL}$ of $4.0 \mathrm{~mol} \mathrm{~L}^{-1}$ sodium hydroxide solutions were added. The contents were diluted to the mark with distilled water and mixed well. After $10 \mathrm{~min}$, the absorbance of the colored azo- dye was measured at $560 \mathrm{~nm}$ against the reagent blank. The amount of drug was computed from the standard calibration graph.

\section{Method $\mathrm{M}_{2}$}

Aliquots of the standard solution containing $0.5-8.0 \mu \mathrm{g} \mathrm{mL}^{-1}$ of MSP were transferred into a series of $10 \mathrm{~mL}$ standard flasks. To each flask were added $1.0 \mathrm{~mL}$ each of the $0.2 \%(\mathrm{~m} / \mathrm{v})$ sodium nitrite and $1.0 \mathrm{~mol} \mathrm{~L}^{-1} \mathrm{HCl}$. After $10 \mathrm{~min}$, a volume of $1.0 \mathrm{~mL}$ each of the $2.0 \%(\mathrm{~m} / \mathrm{v})$ sulphamic acid and $0.5 \%(\mathrm{~m} / \mathrm{v})$ DPA were added. The contents were diluted to the mark with 6.0 mol L-1 $\mathrm{HCl}$ and mixed well. The absorbance of the colored azo- dye was measured at $540 \mathrm{~nm}$ against the reagent blank after $10 \mathrm{~min}$. The amount of drug was computed from the concurrent calibration graph.

\section{Results and discussion}

The proposed methods $\left(\mathrm{M}_{1}\right.$ and $\left.\mathrm{M}_{2}\right)$ are based on the diazo-coupling reaction of the MSP with CTA and DPA in alkaline and acidic medium, respectively. The resulting orange-red colored azo- dye shows maximum absorption at $560 \mathrm{~nm}$ for $\mathrm{M}_{1}$ and at $540 \mathrm{~nm}$ for $\mathrm{M}_{2}$ Figure 1 . Two steps are involved in the reaction that produces the colored dye. In the first step, the studied MSP is treated with nitrite solution in acidic medium, which undergoes diazotisation to give the diazonium chloride ion. In the second step, the formed diazonium ion is coupled with CTA in an alkaline medium $\left(\mathrm{M}_{1}\right)$ and with DPA in an acidic medium $\left(\mathrm{M}_{2}\right)$ to form azo- dyes. The possible reaction pathways for both the procedures are depicted in Scheme 1.

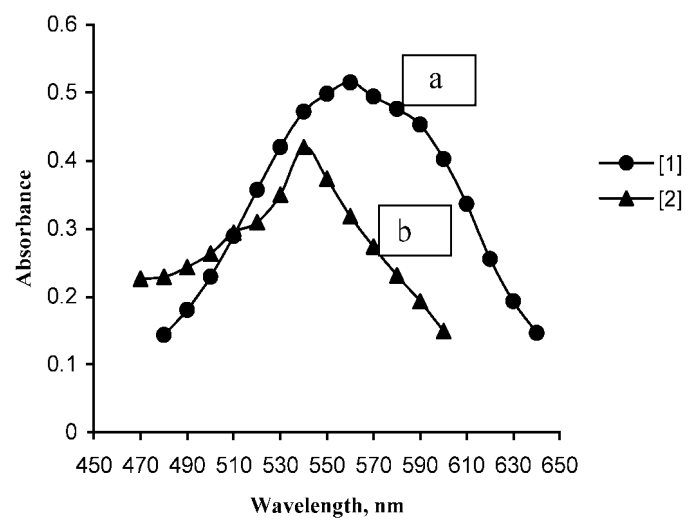

Figure 1. Absorption spectra of [a] MSP (10 $\mu \mathrm{g}$ $\left.\mathrm{mL}^{-1}\right)$ with CTA and [b] MSP $\left(6.0 \mu \mathrm{g} \mathrm{mL}^{-1}\right)$ with DPA measured against reagent blank (without MSP). 


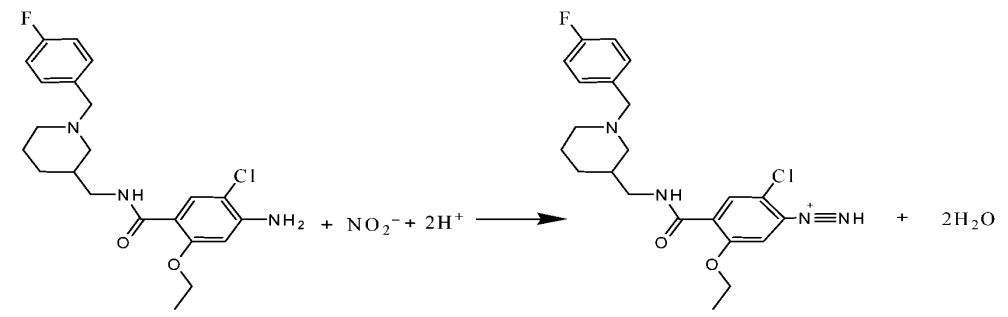

Mosapride[MSP]

Diazonium ion [A]
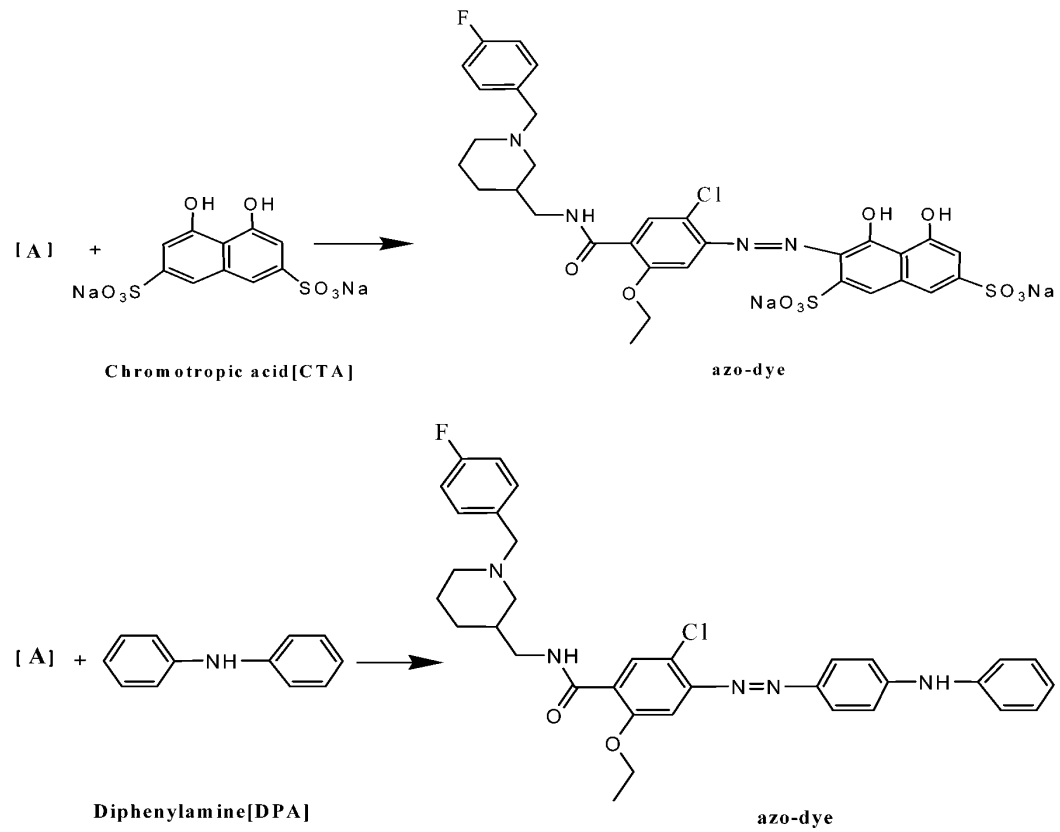

Scheme 1. Proposed chemical reactions between MSP with CTA and DPA.

\section{Optimization of variables}

In order to establish the linear range for quantitative determination of mosapride in pure and in dosage forms, the following experimental variables were studied with $6 \mu \mathrm{g} \mathrm{mL}-1$ of mosapride at $560 \mathrm{~nm}$ and at $540 \mathrm{~nm}$ in methods $\mathrm{M}_{1}$ and $\mathrm{M}_{2}$, respectively.

\section{Effect of sodium nitrite}

For the diazotisation coupling reaction, it was found that $0.2 \%(\mathrm{~m} / \mathrm{v})$ sodium nitrite solution in the range of $0.5-2.0 \mathrm{~mL}$ was optimum to achieve maximum absorbance. Hence, $1.0 \mathrm{~mL}$ of $0.2 \%(\mathrm{~m} / \mathrm{v})$ sodium nitrite solution was employed for diazotisation and excess of nitrite could be removed by the addition of $1.0 \mathrm{~mL}$ of $2 \%(\mathrm{~m} / \mathrm{v})$ sulphamic acid. The effect of sodium nitrite con- centration on the absorbance of the azo- dyes studied is presented in Figure 2.

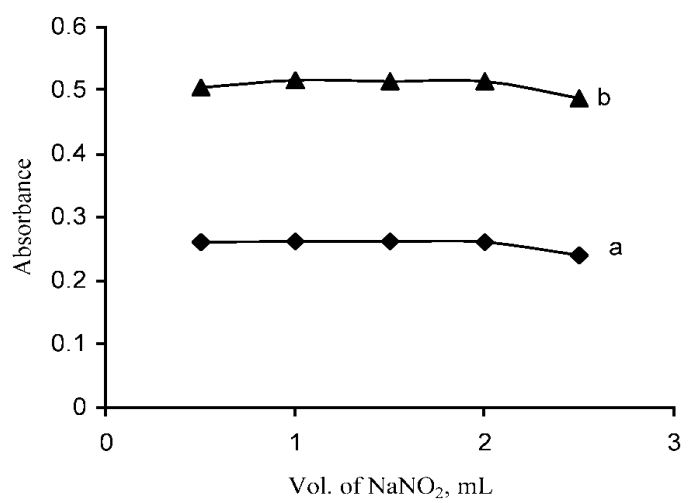

Figure 2. Effect of sodium nitrite on the absorbance of azo- dye in [a] $\mathrm{M}_{1}$ and [b] $\mathrm{M}_{2}$. 
Effects of CTA and DPA

The influence of CTA or DPA concentration on the color intensity of the azo-dye is depicted in Figure 3. The results indicate that the constant absorbance values were obtained in the range $1.0-2.0 \mathrm{~mL} 0.2 \%(\mathrm{~m} / \mathrm{v})$ of CTA or $0.5 \%(\mathrm{~m} / \mathrm{v})$ of DPA. A slight decrease in absorbance of the azo- dye was observed at higher concentrations of CTA or DPA. Thus, further investigations were performed with the use of $1.0 \mathrm{~mL}$ each of $0.2 \%(\mathrm{~m} / \mathrm{v}) \mathrm{CTA}\left(\mathrm{M}_{1}\right)$ and $0.5 \%(\mathrm{~m} / \mathrm{v})$ DPA $\left(\mathrm{M}_{2}\right)$ in a total volume of 10 $\mathrm{mL}$ of the reaction mixture.

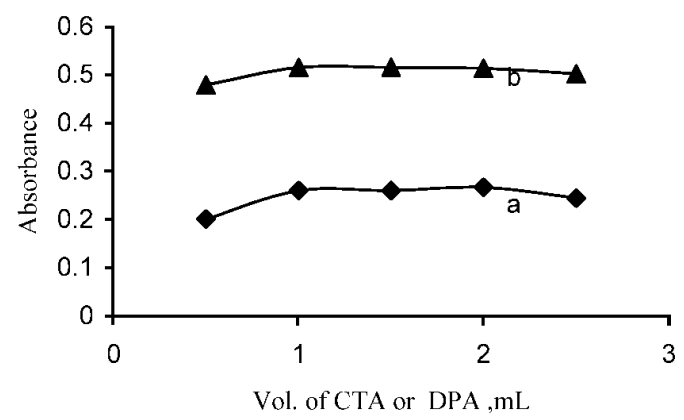

Figure 3. Effect of [a] CTA and [b] DPA on the absorbance of azo- dye.

\section{Effects of reaction time and temperature}

The colored dyes developed rapidly after the addition of reagents and attained maximum intensity after about $5 \mathrm{~min}$ at room temperature (28 $\left.\pm 2{ }^{\circ} \mathrm{C}\right)$. No cooling $\left(0-5^{\circ} \mathrm{C}\right)$ was required for the diazotisation. The formed azo- dyes were stable for more than $3 \mathrm{~h}$.

The stability and formation of an azo-dye depends upon the nature of reaction medium. In method $\mathbf{M}_{1}$, the azo-dye was stable and intense in an alkaline medium. Sodium hydroxide was found to be more suitable for coupling reaction compared to sodium carbonate or aqueous ammonia because the formed dye was stable and more intense in sodium hydroxide medium. Thus, a volume of $2.0 \mathrm{~mL}$ of $4.0 \mathrm{~mol} \mathrm{~L}^{-1} \mathrm{NaOH}$ was used ( $\mathrm{pH} \sim 12)$. The maximum absorbance of the colored azo-dye was obtained in hydrochloric acid medium and it was stable in same acid medium. This was achieved by using $6.0 \mathrm{~mol} \mathrm{~L}^{-1} \mathrm{HCl}$ as a diluent in method $\mathrm{M}_{2}$.

\section{Analytical data}

Optical characteristics such as Beer's law range, molar absorptivity, Sandell's sensitivity, slope, intercept, detection and quantitation limits of both the methods are presented in Table 1 .

Table 1. Optical characteristics and precision data

\begin{tabular}{lcc}
\hline \multicolumn{1}{c}{ Parameter } & $\mathbf{M}_{1}$ & $\mathbf{M}_{2}$ \\
\hline Beer's law limit $\left(\mu \mathrm{g} \mathrm{mL}^{-1}\right)$ & $2.0-16.0$ & $0.5-8.0$ \\
Molar absorptivity $\left(\mathrm{L} \mathrm{mol}^{-1} \mathrm{~cm}^{-2}\right)$ & $1.90 \times 10^{4}$ & $3.92 \times 10^{4}$ \\
Sandell's sensitivity $\left(\mu \mathrm{g} \mathrm{cm}^{-2}\right)$ & 0.0221 & 0.0107 \\
Correlation coefficient $[\mathrm{r}]$ & 0.9999 & 0.9999 \\
Regression equation $\left[\mathrm{Y}^{*}\right]$ & & \\
Slope [b] & & 0.0831 \\
Intercept [a] & 0.0418 & 0.0207 \\
Detection limit [DL] $\left(\mu \mathrm{g} \mathrm{mL}{ }^{-1}\right)$ & 0.3850 & 0.1209 \\
Quantitation limit [QL] $\left(\mu \mathrm{g} \mathrm{mL}^{-1}\right)$ & 1.1667 & 0.3665 \\
\hline
\end{tabular}

*Y $\mathrm{Y}=\mathrm{a}+\mathrm{bx}$, where $\mathrm{x}$ is the concentration in $\mu \mathrm{g} \mathrm{mL}^{-1}$.

\section{Applications}

The proposed methods were successfully applied to the analysis of MSP in various pharmaceutical formulations. The results of assay are given in Table 2 compare favorably with the reference method [7]. Statistical analysis of the results by $\mathrm{F}$ and $\mathrm{t}$-tests showed no significance in accuracy and precession between the proposed and reference methods. To test the accuracy of the methods, recovery experiments were performed on synthetic mixtures of MSP with talc, starch, stearic acid, gum acacia, dextrose, gelatin etc by the proposed methods and recoveries obtained were in the range of 98.9-102.0\%.

\section{Conclusions}

The proposed spectrophotometric methods for the determination of MSP are simple, reliable, sensitive with the advantage of a wide range 
Table 2. Results of assay of mosapride in dosage forms

\begin{tabular}{|c|c|c|c|c|c|c|c|c|}
\hline \multirow[b]{2}{*}{ 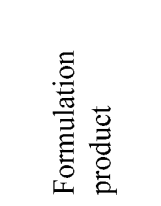 } & \multirow[b]{2}{*}{ 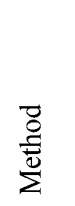 } & \multirow{2}{*}{\multicolumn{2}{|c|}{$\begin{array}{l}\text { Proposed } \\
\begin{array}{l}\text { Amount } \\
\text { found } \\
\left(\mu \mathrm{g} \mathrm{mL}^{-1}\right)\end{array}\end{array}$}} & \multirow{2}{*}{$\frac{\text { Method }^{\mathrm{a}}}{\% \operatorname{Rec} \pm \mathrm{SD}}$} & \multirow{2}{*}{$\begin{array}{c}\text { Reference } \\
\% \text { C V }\end{array}$} & \multirow{2}{*}{$\frac{\text { Method [7] }}{\% \text { Rec. } \pm \text { S D }}$} & \multirow[b]{2}{*}{$t$-value ${ }^{b}$} & \multirow[b]{2}{*}{ F-value } \\
\hline & & & & & & & & \\
\hline \multirow{6}{*}{$\begin{array}{l}\text { Mosapid } \\
5.0 \mathrm{mg} / \mathrm{tab}\end{array}$} & \multirow{3}{*}{$\mathbf{M}_{1}$} & 4.0 & 3.99 & $99.6 \pm 0.27$ & 0.067 & $100.3 \pm 0.33$ & 0.91 & 1.49 \\
\hline & & 8.0 & 8.06 & $100.7 \pm 0.68$ & 0.084 & $99.9 \pm 0.47$ & 1.51 & 2.09 \\
\hline & & 12.0 & 7.09 & $99.5 \pm 0.51$ & 0.043 & $101.7 \pm 0.82$ & 1.66 & 2.58 \\
\hline & \multirow{3}{*}{$\mathbf{M}_{2}$} & 1.0 & 0.99 & $99.9 \pm 0.25$ & 0.250 & $101.1 \pm 0.41$ & 1.60 & 2.68 \\
\hline & & 4.0 & 3.98 & $99.5 \pm 0.70$ & 0.175 & $99.9 \pm 0.37$ & 0.86 & 3.57 \\
\hline & & 7.0 & 7.03 & $100.4 \pm 0.17$ & 0.024 & $100.6 \pm 0.35$ & 1.70 & 4.23 \\
\hline \multirow{6}{*}{$\begin{array}{l}\text { Mosid-MT } \\
5.0 \mathrm{mg} / \mathrm{tab}\end{array}$} & \multirow{3}{*}{$\mathbf{M}_{1}$} & 4.0 & 3.99 & $99.7 \pm 0.62$ & 0.150 & $98.9 \pm 0.48$ & 1.19 & 1.67 \\
\hline & & 8.0 & 7.92 & $99.0 \pm 0.59$ & 0.074 & $100.4 \pm 0.39$ & 1.06 & 2.28 \\
\hline & & 12.0 & 12.11 & $100.9 \pm 0.47$ & 0.038 & $99.9 \pm 0.25$ & 1.85 & 3.53 \\
\hline & \multirow{3}{*}{$\mathbf{M}_{2}$} & 1.0 & 0.99 & $99.7 \pm 0.13$ & 0.130 & $99.9 \pm 0.18$ & 1.84 & 1.92 \\
\hline & & 4.0 & 4.06 & $101.5 \pm 0.29$ & 0.071 & $102.0 \pm 0.51$ & 1.34 & 3.09 \\
\hline & & 7.0 & 6.99 & $99.8 \pm 0.36$ & 0.050 & $101.3 \pm 0.77$ & 1.05 & 4.57 \\
\hline \multirow{6}{*}{$\begin{array}{l}\text { Moza } \\
5.0 \mathrm{mg} / \mathrm{tab}\end{array}$} & \multirow{3}{*}{$\mathbf{M}_{1}$} & 4.0 & 4.02 & $100.5 \pm 0.30$ & 0.074 & $99.9 \pm 0.27$ & 1.71 & 1.23 \\
\hline & & 8.0 & 7.98 & $99.7 \pm 0.63$ & 0.053 & $100.2 \pm 0.40$ & 1.59 & 2.48 \\
\hline & & 12.0 & 11.93 & $99.4 \pm 0.54$ & 0.045 & $99.8 \pm 0.30$ & 1.94 & 3.24 \\
\hline & \multirow{3}{*}{$\mathbf{M}_{2}$} & 1.0 & 0.99 & $99.9 \pm 0.11$ & 0.11 & $100.3 \pm 0.17$ & .813 & 2.38 \\
\hline & & 4.0 & 3.99 & $99.7 \pm 0.49$ & 0.117 & $99.9 \pm .0 .29$ & 1.73 & 2.85 \\
\hline & & 7.0 & 7.04 & $100.5 \pm 0.65$ & 0.089 & $99.7 \pm 0.34$ & 1.99 & 3.65 \\
\hline
\end{tabular}

a Average of five determinations, b Tabulated value 2.78 , c Tabulated value 6.39 .

of determination without the need of extraction or heating. These methods can be successfully applied to the micro determination of mosapride in pure as well as in pharmaceutical preparations.

\section{Acknowledgments}

One of the authors [M.A.V] is thankful to the University of Mysore, Mysore for providing the necessary facilities.

\section{Received 06 August 2007}

Accepted 20 November 2007

\section{References}

[1] T. Karasawa, N. Yoshida, K.Furukawa, H.Omoya, T.Ito, Eur. J.Pharmacol.183 (1990) 2181.
[2] N.Yoshida, T.Ito, K.Furukawa, Z.Ito, J.Pharm.Exp.Ther. 257(1991) 781.

[3] Y.S.R.Krishnaiah, T.K.Murthy, D.G.Sankar, V. Satyanarayana, Anal. Sci., 18 (2002) 1269.

[4] Y.S.R.Krishnaiah, T.K.Murthy, D.G.Sankar, V. Satyanarayana, Pharmazie, 57 (2002) 814.

[5] R.Nageswara Rao, D.Nagaraju, S.N.Alvi, S.B.Bhirud, J.Pharm. Biomed. Anal., 36 (2004) 759.

[6] S.J.Rajput, M.G.Sankalia, F.T.Patel, Indian J.Pharm. Sci., 67 (2005) 582.

[7] B.S.Kuchekar, V.Adagale, M.Nagar, S.B. Bhise, Indian J.Pharm. Sci., 65 (2003) 85.

[8] B.K.Prabhakar, M.Shobha, S.Appala Raju, J.Indian Council of Chemists, 20 (2003) 42.

[9] E.Fagnani, C.B.Melios, L.Pezza, H.R.Pezza, Talanta, 60 (2003) 171.

[10] B.K.Afghan, Ricky Leung, A.V.Kulakarni, J.F.Ryan, Analytical Chemistry, 47 (1975),556.

[11] A.F.Shoukry, N.T.Abdel Ghani, Y.M.Issa,O.A. Wahdan, Analytical Letters,34 (2001) 1689.

[12] A.Afkhami, M.Bahram, S.Gholami and Z.Zand, Anal.Biochem., 33 6(2005) 295.

[13] Y.Feng, S.J.Ji and J.G. Wang, Physical Testing and Chemical Analysis Part B Chemical Analysis, 39(2003 15. [14] C Dave, and L.Caballes, J.Pharm.Sci., 63 (1974) 347. 